\title{
PENDIDIKAN LINGKUNGAN BERWAWASAN GENDER PERSPEKTIF AL-QUR'AN
}

\author{
Hasbi Yatim \\ Institut PTIQ Jakarta \\ Email: hasbiyatim007@gmail.com
}

\begin{abstract}
ABSTRAK
Penelitian ini menjelaskan perspektif Al-Qur'an mengenai pendidikan lingkungan berwawasan gender yang mengusung teori ecopedagogi humanisme teosentris, yakni teori yang memberikan gambaran tentang pendidikan ekologi bagi laki-laki dan perempuan yang terpusatkan pada aturan ekologis dari petunjuk Allah Swt. Melalui pendidikan lingkungan berwawasan gender perspektif Al-Qur'an ini diharapkan dapat membangun kesadaran dan aksi nyata peserta didik dalam upaya menjaga kelestarian dan konservasi lingkungan.

Temuan Penelitian ini mengungkap bentuk-bentuk inisiasi pendidikan lingkungan berwawasan gender dalam perspektif Al-Qur'an yang terdiri dari; Memperhatikan alam raya sebagai manifestasi dari kebesaran Allah Swt ("Aql); Proses observasi terhadap lingkungan (Tadabbur); Pengungkapan rasa syukur atas karunia lingkungan dengan upaya konservasi lingkungan (Tasyakkur); Menjadi saintis pereka cipta temuan yang bermanfaat bagi lingkungan (ulul albab); Penghormatan sebagai rasa tunduk kepada Pencipta alam raya (taskhir); Protektor alam raya (khalifah); Manifestasi atas dimuliakannya manusia (takrim). Kesemuanya tersebut dalam peran-peran sebagai; Ulin Nuha; Ulil Abshar; Ulul Albab; Muhsin; Takrim; Intisyar, bagi laki-laki dan perempuan.

Penelitian ini memiliki kesamaan mengenai pembahasan tentang kesetaraan gender dari manusia terhadap lingkungannya, yakni dengan: Nasaruddin Umar (2001), Muhammad Quraish Shihab (2005), dan Nur Arfiyah Febriani (2014). Serta kesamaan pembahasan tentang pendidikan lingkungan dengan Faulo Preire (1972) dan Nana Supriatna (2016).

Penelitian ini memiliki perbedaan dengan pendapat yang menyatakan bahwa kerusakan lingkungan memiliki korelasi dengan sikap dominatif laki-laki terhadap perempuan dengan para tokoh feminis seperti: Carolyn Merchant (1992), Robyn Eckersley (2001), Jean Shinoda Bolen (2004) dan Nawal Amar (2009). Penelitian ini juga memiliki perbedaan kajian dengan Adudin Alijaya (2019) yang fokus pada pembahasan konsep ekopedagogi dalam Al-Qur'an.

Metode penelitian yang digunakan dalam Penelitian ini adalah kualitatif, sedangkan metode penafsiran yang digunakan adalah metode tafsir Maudhu'i, Kedua metode tersebut digunakan agar menghasilkan data deskriptif melalui observasi terhadap surat dan ayat Al-Qur'an, serta sains yang terkait dengan pembahasan Penelitian, kemudian dibantu visualisasinya dengan tabel-tabel.
\end{abstract}

Kata kunci : Al-Qur'an, kesetaraan gender 


\begin{abstract}
This Research explane about Qur'anic perspectives on environmental education insightful about gender that follows the theory ecopedagogi teosentris humanism, namely the ecology that provides a description of education for all people without any centered gender guidance to rule ecology of Allah, to them can select from its potential in terms of damage or doing environmental conservation with responsible for his choice.

The findings of this Research uncover of forms initiation of environmental education insightful gender in Qur'anic perspectives that consist of; pay close attention to order of the universe as in the manifestations of the greatness of god ( " $A q l$ ); the process of observation to the environment (tadabbur); the disclosure of a sense of thanks on the environment with the effort to environmental conservation (tasyakkur); become saintis inventor of discovery that a lot of useful information derogatory term for environmentalists (ulul albab); homage as fill up with awe in the lord of universe (taskhîr); protektor of the universe (a caliph); a manifestation of over glorified human being (takrim). Oll of the title referred as roles; Ulin Nuha; Ulil Abshar; Ulil Albab; muhsin; takrim; intisyar for men and women.

The Research have in common about the discussion of gender equality of human being to its environment, namely with: Ibn 'Adil al-Hanbali (w.880 h), alMaragi (L.1881 m), Faulo Preire (1972) Sachiko Murata (1992), Nasaruddin Umar (2001), Muhammad Quraish Shihab (2005), Nur Arfiyah Febriani (2014), and Nana Supriatna (2016).

The findings of this Research have a difference in a statement the environmental damage, having the correlation with men domination attitudes against women with the leaders of feminist like: Carolyn Merchant (1992), Robyn Eckersley (2001), Jean Shinoda Bolen (2004) and Nawal Amar (2009). This Research also have difference statement with Adudin Alijaya (2019) that focus on statement of ecopedagogi concept in Al-Qur'an.

Research methodology that used on this Research is qualitative methodology and methods of interpretation is al-maudhu'i. Both of this methods are used to produce data descriptive through observation to letters and Al-Qur'an verses, and the science which relating to discussion of Research, then assisted visualization with tables.
\end{abstract}

Keywoard: Al-Qur'an, gender equality 


\section{Pendahuluan}

Pembahasan tentang masalah lingkungan sampai saat ini hangat diperbincangkan dan selalu aktual. Berawal dari temuan yang menyatakan bahwa lapisan ozon, kini semakin menipis, dengan terus menipisnya lapisan itu, sangat dikhawatirkan bila lapisan ini tidak ada, atau menghilang sama sekali dari alam semesta ini. Tanpa lapisan ozon sangat banyak akibat negatif yang akan menimpa makhluk hidup di muka bumi ini, antara lain, cuaca tidak menentu, penyakitpenyakit akan menyebar secara menjadi-jadi, pemanasan global, bahkan hilangnya suatu daerah akan terjadi karena mencairnya es yang ada di kutub utara dan selatan. Alam semesta seakan hanya tinggal menunggu masa kehancurannya saja, para ilmuwan menyatakan banyak cara yang harus dipilih untuk mengatasi masalah ini dengan memberikan berbagai masukan sesuai dengan latar belakang keilmuannya masing-masing. Diantara contoh penyebab dan dampak lingkungan lokal adalah kekeringan, banjir, longsor, erosi pantai dan instrusi air laut. ${ }^{1}$

Berkaitan dengan lingkungan hidup, Siahaan mengatakan bahwa faktor terpenting dalam permasalahan lingkungan adalah lajunya pertumbuhan penduduk atau besarnya populasi manusia. Pertumbuhan penduduk yang pesat menimbulkan tantangan yang harus diatasi dengan pembangunan dan industrialisasi. Industrialisasi disamping mempercepat perse-diaan segala kebutuhan hidup manusia, sering kali memberi dampak negatif terhadap manusia itu sendiri, akibat terjadinya pencemaran lingkungan yang dihasilkan dari indusrti tersebut. Sebelumnya banyak yang menduga adanya masalah isu lingkungan global lebih banyak dipengaruhi faktor alam. Seperti iklim, yang mencakup temperatur, curah hujan, kelembaban, tekanan udara dan lain-lain. Pada akhirnya mulai disadari bahwa aktifitas manusia pun mempengaruhi perubahan iklim dan lingkungan secara signifikan. Sebagi contoh penebangan hutan, yang mempengaruhi perubahan suhu dan curah hujan secara lokal, sehingga ketika area hutan yang hilang semakin luas, maka akibat yang ditimbulkan bukan lagi lokal tapi sudah berskala regional. Motivasi manusia menebang hutan, diantaranya adalah motivasi ekonomi. Untuk skala negara, negara membutuhkan devisa dalam menjalankan roda pembangunan. Karena industri negara belum mapan dan kuat, maka yang bisa diekspor untuk menambah devisa adalah menjual kayu. Modal dan keahlian yang dibutuhkan untuk menebang pohon relatif kecil dan sederhana, tetapi akibat yang terjadi ternyata menjadi masalah global yang mempengaruhi lingkungan juga. $^{2}$

Oleh karena itu, menurut hemat penulis bahwa pertumbuhan penduduk dunia yang amat pesat memiliki arti pertumbuhan kawasan urban dan juga kebutuhan tambahan produksi pangan, peningkatan kebutuhan energi menjadi salah satu faktor penyebab kerusakan alam. Dari berbagai kebutuhan tersebut memiliki implikasi pada lingkungan sebagai konsekuensi logis. Penulis memberi contoh dari kebutuhan lahan urban dan lahan pertanian. Pemenuhan kebutuhan ini akan meminta konversi lahan hutan. Semakin lama daerah-daerah resapan air makin berkurang, akibatnya terjadi krisis air tanah.

\footnotetext{
${ }^{1}$ Bernadette West, Peter M. Sandman, Michael R. Greenberg. Paduan Pemberitaan Lingkungan Hidup. Jakarta: Yayasan Obor Indonesia, 1998, hal. 132. Lihat juga dalam Mc Elroy, C.T., Fogal, P.F. "Ozone: From Discovery To Protection": Atmosphere This Can Also Effect Drop Bears/Ocean. 2008, hal. 1-13.

${ }^{2}$ Siahaan N.H.T, Hukum Lingkungan dan Ekonomi Pembangunan, Jakarta: Erlangga, 2004, hal. 125-126.
} 
Selain itu kecenderungan manusia moderen saat ini dalam memanfaatkan dan mengelola lingkungan hidup berprilaku nir-etika. Nir-etika adalah prilaku tanpa nurani, tidak sadar bahwa alam adalah ciptaan Allah Swt, dan tidak menyadari alam merupakan bagian dari hidup manusia.

Sesungguhnya yang menyebabkan kerusakan alam adalah bukan saja lakilaki, tetapi perempuan juga memiliki potensi membuat kerusakan di muka bumi.

"Telah nampak kerusakan di darat dan di laut disebabkan karena perbuatan tangan manusia, supaya Allah merasakan kepada mereka sebahagian dari (akibat) perbuatan mereka, agar mereka kembali (ke jalan yang benar)." (QS, ar-Rum/30: 41).

Peran dalam kehidupan yang paling menonjol adalah bagaimana lingkungan hidup ikut pula mempengaruhi pendidikan. Pendidikan yang merupakan salah satu aspek penting dalam kehidupan menjadi sorotan dalam pengembagan lingkungan hidup. Khususnya tentang pendidikan lingkungan hidup. Salah satu aspek utama dalam memajukan pendidikan lingkungan hidup adalah dengan mengembangkan kurikulum lingkungan hidup yang telah ada. Sejak Institut Keguruan Ilmu Pendidikan menyelenggarakan program pendidikan lingkungan hidup pada 1975, pendidikan lingkungan hidup terus berkembang hingga saat ini. ${ }^{3}$

\section{Pembahasan}

Pada dasarnya manusia itu tidak memiliki pengeta-huan apapun sejak dilahirkan, ${ }^{4}$ pendidikan yang meru-bah manusia menjadi tahu apa saja yang diinginkan. Oleh karena itu pendidikan sudah menjadi kebutuhan primer dalam kehidu-pan. Secara alamiah pendidikan sudah menjadi kebutuhan hidup manusia, termasuk dalam hal pendidikan lingkungan.

Definisi lingkungan adalah gabungan semua hal yang mempengaruhi hidup kita, kesatuan ruang dengan semua benda, daya, keadaan, dan mahluk hidup, termasuk manusia dan perilakunya, yang mempe-ngaruhi kelangsungan prikehidupan dan kesejahteraan manusia serta mahluk hidup lain. ${ }^{5}$ Sebagaimana dituang-kan dalam undang-undang tentang pelindungan dan pengelolaan lingkungan hidup nomor 32 tahun 2009.

Pendidikan lingkungan juga diartikan sebagai suatu proses yang bertujuan untuk mengembangkan kesadaran umat manusia akan lingkungan hidup dengan seluruh permasalahan yang terdapat didalamnya. ${ }^{6}$ Pendidikan lingkungan dapat pula diartikan sebagai wahana untuk merubah perilaku individu menjadi perilaku yang positif terhadap lingkungan. ${ }^{7}$ Pendidikan Lingkungan merupakan salah satu upaya menanamkan sikap cinta lingku-ngan pada anak bangsa.

Dapat disimupulkan, pendidikan lingkungan adalah upaya mengubah perilaku dan sikap yang dilakukan oleh berbagai elemen masyarakat dengan tujuan untuk meningkatkan pengetahuan, kecerda-san, keterampilan dan kesadaran

3 Lihat dalam http://www.menlh.go.id/informasi-mengenai-adiwiyata/, diakses pada tanggal 10/02/2017.

${ }^{4}$ Lihat Qs. An-Nahl/16: 78.

${ }^{5}$ Wiryono, Pengantar Ilmu Lingkungan.,.., 2013, hal. 1-2. Lihat pula Mundiatun, Pengantar Pendidikan Lingkungan Hidup,..., hal.19 Lihat juga Yonatan Pongtuluran, Manajemen Sumberdaya Alam \& Lingkungan, Yogyakarta: Andi, 2013, hal. 51.

${ }^{6}$ R.E. Soeriatmadja, Ilmu lingkungan, Bandung : Penerbit ITB, 1997, hal. 3.

${ }^{7}$ R. Meilani, Persepsi Guru dalam Penerapan Pendidikan Lingkungan Hidup di Sekolah Dasar, Bogor: Institut Pertanian Bogor, 2011, hal. 7. 
masyarakat tentang nilai-nilai lingkungan dan isu permasalahannya, yang pada akhirnya dapat menggerakkan masyarakat agar berperan aktif dalam upaya pelestarian dan penyela-matan lingkungan untuk kepentingan generasi seka-rang dan yang akan datang.

Di dalam Undang-Undang Nomor 20 tahun 2003 tentang Sistem Pendidikan Nasional, Pasal 3, tujuan pendidikan nasional adalah mengembangkan potensi peserta didik agar menjadi manusia yang beriman dan bertakwa kepada Tuhan Yang Maha Esa, berakhlak mulia, sehat, berilmu, cakap, kreatif, mandiri, dan menjadi warga negara yang demokratis serta bertanggung jawab. ${ }^{8}$

Ibnu Sina berpendapat, tujuan pendidikan memiliki tiga fungsi yang bersifat normatif. Pertama, tujuan itu menentukan haluan bagi proses pendidikan. Kedua, tujuan memberi rangsangan. Ketiga, tujuan adalah nilai. Ibnu Sina berkesimpulan tujuan pendidikan harus diarahkan pada pengembangan seluruh potensi yang dimiliki seseorang kearah perkembangan yang sempurna, yaitu perkembangan fisik, intelektual dan budi pekerti. ${ }^{9}$

Menurut M.J. Lavengeld, bahwa tujuan umum pendidikan adalah kedewasaan atau manusia dewasa, yaitu manusia yang menentukan sendiri secara mandiri atas tanggung jawab sendiri. Pengertian lain tentang tujuan umum pendidikan adalah mampu melaksanakan tugas dari Tuhan dengan sebaik-baiknya, melaksanakan tugas kemanusiaan, melaksanakan tugas sebagai warga negara, mampu melaksanakan tugas kemasyarakatan, serta mampu melaksnakan tugas sebagai pribadi yang utuh. ${ }^{10}$

Sedangkan menurut Muhammad Fadhlil Al-Jamali, tujuan pendidikan itu dapat di simpulkan menjadi empat bagian: ${ }^{11}$

a. Mengenalkan manusia akan peranannya diantara sesama manusia dan tanggungjawab pribadinya di dalam hidup ini.

b. Mengenalkan manusia akan interaksi sosial dan tanggungjawabnya dalam tata kehidupan.

c. Mengenalkan manusia akan ala mini, mengajak mereka memahami hikmah diciptakannya serta memberikan kemungkinan kepada mereka untuk dapat mengambil manfaat dari alam tersebut.

Pendidikan lingkungan memiliki tujuan seperti yang dirumuskan pada waktu konferensi antar Negara tentang pendidikan lingkungan pada tahun 1975 di Tbilisi, yaitu meningkatkan kesadaran yang berhubungan dengan saling ketergantungan ekonomi, sosial, politik dan ekologi antara daerah perkotaan dan pedesaaan memberikan kesempatan kepada setiap individu untuk memperoleh pengetahuan nilai-nilai dan sikap tanggung jawab keterampilan yang dibutuhkan untuk melindungi dan meningkatkan lingkungan, menciptakan pola baru prilaku

${ }^{8}$ https://www.google.co.id/search?q=tujuan+pendidikan\&oq=tujuan, diakses pada tanggal 25/11/2017.

${ }^{9}$ Abu Muhammad Iqbal, Pemikiran Pendidikan Islam, Yogyakarta: Pustaka Pelajar, 2015, hal. 6 .

${ }^{10}$ https://metirosmiati.wordpress.com/2013/01/10/tujuan-pendidikan, diakses pada tanggal 22/10/2017.

${ }^{11}$ Muhammad Fadhlil Al-Jamali, Konsep Pendidikan Qur'ani Sebuah Kajian Filosofis, Solo: Ramadhani, 1993, hal. 12-13. 
individu, kelompok dan masyarakat secara menyeluruh menuju lingkungan yang sehat, serasi dan seimbang. ${ }^{12}$

Pada konferensi Tbilisi tahun 1997 juga dikemukan tentang tujuan umum pendidikan lingkungan, seperti yang dikemukakan Muhaimin dalam buku Membangun Kecerdasan Ekologis, sebagai berikut: ${ }^{13}$

a. Untuk membantu menjelaskan masalah kepedulian serta perhatian tentang saling keterkaitan antara ekonomi, sosial, politik, dan ekologi di kota maupundi wilayah pedesaan.

b. Untuk memberikan kesempatan kepada setiap orang dalam mengembangkan pengetahuan, nilai, sikap, komitmen, dan kemampuan yang dibutuhkan untuk melindungi dan memperbaiki lingkungan.

c. Untuk menciptakan pola perilaku yang baru pada individu, kelompok, dan masyarakat sebagai suatu keseluruhan terhadap lingkungan. Tujuan tersebut meliputi: pengetahuan, sikap, kepedulian, keteram-pilan dan partisipasi.

Sedangkan menurut Kementerian Lingkungan Hidup, tujuan pendidikan lingkungan hidup adalah mendorong dan memberikan kesempatan kepada masyarakat memperoleh pengetahuan, keterampilan, dan sikap yang pada akhirnya dapat menumbuhkan pengetahuan, keterampilan, dan sikap yang pada akhirnya dapat menumbuhkan kepedulian, komitmen untuk melindungi, memperbaiki serta memanfaatkan lingkungan hidup secara bijaksana, turut menciptakan pola prilaku baru yang bersahabat dengan lingkungan, mengembangkan etika lingkungan hidup dan memperbaiki kualitas hidup. ${ }^{14}$

\section{Gender Dalam Pendidikan}

Dari segi etimologi, kata gender berasal dari bahasa Inggris gender yang berarti jenis kelamin. ${ }^{15}$ Berdasarkan arti kata tersebut, gender sama dengan seks yang juga berarti jenis kelamin. Banyak ahli yang merevisi definisi ini. Definisi "gender" tidak hanya mencakup masalah jenis kelamin. Tapi lebih dari itu, analisis gender lebih menekankan pada lingkungan yang membentuk pribadi seseorang. Dalam Webster's New World Dictionarary, gender diartikan sebagai perbedaan yang tampak antara laki-laki dan perempuan dilihat dari segi nilai dan tingkah laku. ${ }^{16}$ Menurut Heyzer gender adalah peranan laki-laki dan perempuan dalam tingkah laku sosial yang terstruktur, ${ }^{17}$ sedangkan Illich berpendapat, gender dimaksudkan untuk membedakan laki-laki dan perempuan secara sosial, yang mengacu pada unsur kejiwaan, emosional dan tingkah laku. ${ }^{18}$ Gender juga diartikan sebagai suatu konsep kultural yang berupaya membuat perbedaan dalam hal peran,

${ }^{12}$ Mundiatun, Pengantar Pendidikan Lingkungan Hidup, Yogyakarta, Gava media, 2002, hal.11. Lihat pula Dendasurono Prawiroatmodjo, Pendidikan lingkungan Kelautan, Jakarta: Rineka Cipta, 1996, hal. 9.

${ }^{13}$ Muhaimin, Membangun Kecerdasan Ekologis, Bandung: Alfabeta, 2015, hal. 30.

${ }^{14}$ Muhaimin, Membangun Kecerdasan Ekologis, ..., hal. 30.

${ }^{15}$ John M. Echols dan Hassan Sadily, Kamus Inggris Indonesia, Jakarta: Gramedia, 2000, hal. 265, lihat pula di dalam Kamus Besar Bahasa Indonesia, edisi keempat, Jakarta: Departemen Pendidikan Nasional, 2008, hal. 439.

16 Victoria Neufeldt, Webster's New World Dictionarary, New York: Webster's New World Clevenland, 1984, hal. 561.

${ }^{17}$ Nur Syam, Agama Pelacur; Dramaturgi Transendental, Yogyakarta: Lkis Pelangi Aksara, 2004, hal. 13.

18 Nur Syam, Agama Pelacur; Dramaturgi Transendental,..., hal. 13. 
perilaku, mentalitas, dan karakteristik emosional antara laki-laki dan perempuan dalam masyarakat. ${ }^{19}$

Di dalam buku Sex and Gender: An Introduction, Hillary M. Lips mengetengahkan arti gender sebagai harapan-harapan budaya terhadap laki-laki dan perempuan yang berkembang dalam masyarakat. ${ }^{20}$ Sedangkan H.T. Wilson dalam bukunya Sex and Gender, sebagaimana dikutif oleh Nasaruddin Umar mendefinisikan gender sebagai suatu dasar untuk menentukan perbedaan sumbangan laki-laki dan perempuan dilihat dari konstruksi sosial budaya. ${ }^{21}$

Gender berbeda dengan jenis kelamin secara biologis. Jenis kelamin merupakan pemberian, ketika dilahirkan sebagai seorang laki-laki atau seorang perempuan. Gender adalah seperangkat peran, seperti halnya kostum dan topeng di dalam teater yang menyampaikan kepada orang lain bahwa pemeran adalah feminin atau maskulin..$^{22}$ Perangkat perilaku khusus ini yang mencakup penampilan, pakaian, sikap, kepribadian, bekerja di dalam dan di luar rumah tangga, seksualitas, tanggung jawab keluarga dan sebagainya secara bersama-sama memoles peran gender..$^{23}$

Gender menjadi topik perbincangan yang selalu hangat karena perbedaan persepsi tentang gender dan jenis kelamin, hal ini berimplikasi terhadap hubungan gender yang timpang antara laki-laki dan perempuan, serta pengembangan kualitas hidup keduanya. Akhirnya banyak orang mengira masalah keadilan dan kesetaraan gender dalam kehidupan sebagai usaha perempuan untuk menyaingi laki-laki.

Untuk memahami konsep gender harus dibedakan kata gender dengan kata seks (jenis kelamin). Pengertian jenis kelamin merupakan pensifatan atau pembagian dua jenis kelamin manusia yang ditentukan secara biologis yang melekat pada jenis kelamin tertentu. Sedangkan konsep lainnya adalah konsep gender yakni suatu sifat yang melekat pada kaum laki-laki maupun perempuan sebagai konstruksi sosial maupun cultural. ${ }^{24}$

Perbedaan jenis kelamin tersebut meliputi perbedaan komposisi kimia dan hormon dalam tubuh, anatomi fisik, reproduksi dan karakteristik biologis lainnya. Seks (jenis kelamin) dibedakan berdasarkan faktor-faktor biologis hormonal dan patologis sehingga muncul dikotomi laki-laki dan perempuan. ${ }^{25}$ Jenis kelamin lakilaki ditandai dengan adanya penis, testis, dan sperma, sedangkan perempuan mempunyai vagina, payudara, ovum dan rahim. Perbedaan biologis tersebut sifatnya kodrati, atau tidak dapat dirubah karena itu semua pemberian Tuhan.

${ }^{19}$ Hellen Tierney (ed), Womewn's Studies Encyclopedia, New York: Green World Press, t.th, Vol, 1, hal.153, lihat Nasaruddin Umar, Argumen Kesetaraan Jender Persfektif Al-Qur'an, Jakarta: Dian Rakyat, 2010, hal. 30, lihat pula, Zaitunah Subhan, Al-Qur'an dan Perempuan Menuju Kesetaraan Gender Dalam Penafsiran, Jakarta: Prenadamedia, 2015, hal.1, lihat pula, Nur Arfiyah Febriani, Ekologi Berwawasan Gender dalam Perspektif Al-Qur'an, Bandung: mizan, 2014, hal. 122 .

${ }^{20}$ Hillary M. Lips, Sex and Gender: An Introduction, London: Mayfied Publishing Company,1993, hal. 4.

${ }^{21}$ Nasaruddin Umar, Argumen Kesetaraan Jender Persfektif Al-Qur'an, Jakarta: Dian Rakyat, 2010, hal. 30.

${ }^{22}$ Julia Cleves Mosse, Gender \& Pembangunan, Yogyakarta: Pustaka Pelajar, 1996, hal.3.

${ }^{23}$ Julia Cleves Mosse, Gender \& Pembangunan,..., hal. 3.

${ }^{24}$ Mansour Fakih, Analisis Gender \& Transformasi Sosial, Yogyakarta: Pustaka Pelajar, 1996, hal. 8 .

${ }^{25}$ Nasaruddin Umar, Argumen Kesetaraan Jender Persfektif Al-Qur'an,..., hal. 35, lihat, Zaitunah Subhan, Al-Qur'an dan Perempuan Menuju Kesetaraan Gender Dalam Penafsiran,..., hal. 2, lihat pula, Siti Fatimah dan Wirdanengsih, Gender dan Pendidikan Multikultural, Jakarta: Kencana, 2016, hal. 2. 
Hal yang penting untuk diperhatikan dalam membahas masalah kaum perempuan adalah pemahaman terhadap konsep seks (jenis kelamin) dan konsep gender. Pembedaan terhadap kedua konsep tersebut perlu dilakukan agar tidak ada kerancuan dalam pemahaman tentang gender dan ketidakadilan gender. Ketidakjelasan makna seks dan gender mengakibatkan timbulnya kekeliruan dalam pembagian peran antara laki-laki dan perempuan dalam masyarakat.

Berbeda dengan konsep seks, gender dipahami sebagai suatu dasar untuk menentukan perbedaan sumbangan laki-laki dan perempuan pada kebudayaan dan kehidupan kolektif. Sehingga gender juga dipahami sebagai suatu konsep yang digunakan untuk mengidentifikasi perbedaan antara laki-laki dan perempuan dilihat dari segi sosial dan budaya non biologis. $^{26}$

Konsep gender tersebut mengacu pada seperangkat sifat, peran, tanggung jawab, fungsi, hak dan perilaku yang melekat pada diri laki-laki dan perempuan akibat bentukan budaya atau lingkungan masyarakat tempat manusia itu tumbuh dan dibesarkan. Timbullah dikotomi maskulin (laki-laki) dan feminin (perempuan).

Pengertian gender tersebut berimplikasi pada munculnya pandangan bahwa perempuan memiliki sifat feminin, diantara sifat feminin itu adalah lemah lembut, cantik, emosional, dan keibuan. Sedangkan laki-laki memiliki sifat maskulin, diantaranya dianggap sebagai pribadi yang memiliki karakteristik kuat, perkasa dan rasional. Pembedaan sifat laki-laki dan perempuan tersebut sebenarnya bisa saling dipertukarkan, artinya bisa saja laki-laki memiliki sifat yang lemah lembut, emosional dan keibuan, sementara perempuan mempunyai sifat kuat, perkasa, rasional dan sebagainya.

\section{Term Pendidikan Lingkungan dalam Al-Qur'an Berwawasan Gender}

1. Kesetaraan Gender dalam Memperhatikan Alam Raya Sebagai Manifestasi Ciptaan Allah "عقل ('Aql). Qs. Âli “Imrân/3: 190191.

2. Kesetaraan Gender dalam Observasi Lingkungan. (Tadabbur)(al-Nisâ/4; 82).

3. Laki-laki dan Perempuan Bersyukur dengan Upaya Konservasi (Tasyakkur(QS, al-‘Araf/7: 10)

4. Laki-laki dan Perempuan Sebagai Saintis Penggagas Temuan Bermanfaat (Ulul Albâb) (QS, al-Nahl/16: 78).

5. Kesetaraan Gender dalam Menghormati Ketundukan Alam Raya (Taskhîr)(QS, al- An'am /6: 38)

6. Laki-laki dan Perempuan Sebagai Protektor Alam Raya (Khalîfah). (QS, al-An'am/6: 165) (QS, al-Baqoroh/2: 30)

7. Laki-laki dan Perempuan Konservator Alam Semesta (Muhsin)

\footnotetext{
${ }^{26}$ Nasaruddin Umar, Argumen Kesetaraan Jender Persfektif Al-Qur'an,..., hal. 31.
} 
Tabel Term Muhsinîn $^{27}$

\begin{tabular}{|c|l|l|l|}
\hline$\underline{\underline{\text { No }}}$ & $\underline{\text { Term }}$ & $\underline{\text { Surat/Ayat }}$ & \multicolumn{1}{|c|}{ Tema/ Isi Kandungan } \\
\hline 7 & Muhsinîn/33 & & \multicolumn{1}{|c|}{} \\
\hline 1 & & $7 / 56$ & $\begin{array}{l}\text { Allah yang meniupkan angin sebagai } \\
\text { kabar gembira, akan turun hujan }\end{array}$ \\
\hline 2 & & $\begin{array}{l}\text { Allah menjamin keberkahan hidup pada } \\
\text { orang yang berbuat baik dan tunduk } \\
\text { kepada-Nya }\end{array}$ \\
\hline
\end{tabular}

8. Laki-laki dan Perempuan sebagai Penjelajah Lingkungan (Intisyar). (QS, alJumah/62: 10)

Kalimat fantasyirû fil ard di dalam Tafsir Al-Maraghi dijelaskan bahwa setelah selesai melakukan salat Jumat, umat Islam boleh bertebaran di muka bumi untuk melaksanakan urusan duniawi, dan berusaha mencari rezeki yang halal, sesudah menunaikan yang bermanfaat untuk akhirat. Hendaklah mengingat Allah sebanyak-banyaknya dalam mengerjakan usahanya dengan menghindarkan diri dari kecurangan, penyelewengan, dan lain-lainnya. ${ }^{28}$ Allah Maha Mengetahui segala sesuatu yang tersembunyi apalagi yang tampak nyata, sebagaimana firman Allah: (QS. At-Tagabun/64: 18) Dengan demikian, tercapailah kebahagiaan dan keberuntungan di dunia dan di akhirat. Dianjurkan kepada siapa yang telah selesai salat Jumat membaca doa yang biasa dilakukan oleh Arrak bin Malik "Ya Allah! Sesungguhnya aku telah memenuhi panggilan-Mu, dan melaksanakan kewajiban kepada-Mu, dan bertebaran (di muka bumi) sebagaimana Engkau perintahkan kepadaku, maka anugerahkanlah kepadaku karunia-Mu. Engkaulah sebaik-baik Pemberi rezeki." (Riwayat Ibnu Abi Hatim). ${ }^{29}$

Ayat di atas dapat di fahami bahwa apabila shalat jum'ah sudah selesai dilaksanakan, maka orang yang shalat di anjurkan atau boleh bertebaran di muka bumi, dalam arti, dianjurkan untuk melaksanakan urusan duniawi, dan berusaha mencari rezeki yang halal, sesudah menunaikan yang bermanfaat untuk akhirat.

Dialah yang menjadikan bumi itu mudah bagi kamu, Maka berjalanlah di segala penjurunya dan makanlah sebahagian dari rezki-Nya. dan hanya kepada-Nya-lah kamu (kembali setelah) dibangkitkan. (alMulk/67: 15)

Ayat ini menerangkan nikmat Allah yang tiada terhingga yang telah dilimpahkan-Nya kepada manusia, dengan menyatakan bahwa Allah telah menciptakan bumi dan memudahkannya untuk mereka, sehingga mereka dapat mengambil manfaat yang tidak terhingga untuk kepentingan hidup mereka. Dia menciptakan bumi itu bundar dan melayang-layang di angkasa luas. Manusia tinggal di atasnya seperti berada di tempat yang datar terhampar, tenang, dan tidak

${ }^{27} 2 / 58,2 / 195,2 / 236,3 / 134,3 / 148,5 / 13,5 / 85,5 / 93,6 / 84,9 / 91,9 / 120,11 / 115,12 / 22,12 / 36$ ,12/56, 12/78, 22/37, 29/69, 31/3, 37/80, 37/105, 37/110, 37/121, 37/131 dan 39/34.

${ }^{28}$ Ahmad Mustofa Al-Maraghi, Tafsir al-Maraghi, Juz 28,..., hal. 102.

${ }^{29}$ Kementerian Agama RI, Al-Qur'an dan Tafsirnya, lihat, https://risalahmuslim. id/quran/al-jumuah/62-10. Diakses 27/8/2019. 
bergoyang. Dengan perputaran bumi terjadilah malam dan siang, sehingga manusia dapat berusaha pada siang hari dan beristirahat pada malam hari. Bumi memancarkan sumber-sumber mata air, yang mengalirkan air untuk kebutuhan manusia dan binatang ternak peliharaannya. Dengan air itu pula manusia mengairi kebun-kebun dan sawah-sawah mereka, demikian pula kolam-kolam tempat mereka memelihara ikan. Dengan air itu pula mereka mandi membersihkan badan mereka yang telah kotor, sehingga mereka merasa segar dan nyaman. DiciptakanNya pula bukit-bukit, lembah-lembah, gunung-gunung yang menghijau yang menyejukkan hati orang yang memandangnya. Dari celah-celah bukit itu mengalirlah sungai-sungai dan di antara bukit-bukit dan lembah-lembah itu manusia membuat jalan-jalan yang menghubungkan suatu negeri dengan negeri yang lain. Betapa banyaknya nikmat yang telah dilimpahkan Allah kepada manusia. Seandainya Allah menahan suatu nikmat saja kepada manusia, misalnya tidak memberikan udara yang akan dihirup, manusia akan mengalami penderitaan yang sangat dahsyat. ${ }^{30}$

Menurut para saintis, bumi yang diseliputi atmosfer sangat dinamis. Prosesproses geologi yang mencakup dari proses erosi, pengendapan, naik-turun muka laut, gempa bumi, pergerakan magma, sampai ke letusan gunung api dalam rentang waktu jutaan tahun telah memungkinkan terjadinya cebakan-cebakan mineral maupun energi. Di bagian lain, laut dan atmosfer pun tak kalah dinamisnya. Interaksinya dengan daratan dan perjalanannya bersama bulan mengitari matahari membentuk iklim dan musim. Proses-proses dinamis yang melibatkan daratan-laut dan atmosfer tersebut memungkinkan terjadinya siklus hidrologi yang pada gilirannya menurunkan hujan dan menyebabkan kesuburan tanah serta terbentuknya cadangan air baik di danau, sungai maupun dalam tanah. Oksigen dan air yang merupakan kebutuhan vital manusia tersedia melimpah dan amat mudah didapatkannya. ${ }^{31}$

Ayat ini menyatakan bahwa dengan sifat rahman-Nya kepada seluruh umat manusia, maka Allah bukan saja telah menyediakan seluruh sarana dan prasarana bagi manusia. Ia juga telah memudahkan manusia untuk hidup di permukaan bumi. Manusia diperintahkan Allah untuk berjalan di permukaan bumi untuk mengenali baik tempatnya, penghuninya, manusianya, hewan dan tumbuhannya. Manusia tidak saja diberi udara, tumbuhan, hewan, dan cuaca yang menyenangkan, tapi juga diberi perlengkapan dan kenyamanan untuk mencari rezeki di bumi dengan segala yang ada di atasnya maupun terkandung di dalamnya. Setelah Allah menerangkan bahwa alam ini diciptakan untuk manusia dan memudahkannya untuk keperluan mereka, maka Dia memerintahkan agar mereka berjalan di muka bumi, untuk memperhatikan keindahan alam, berusaha mengolah alam yang mudah ini, berdagang, beternak, bercocok tanam dan mencari rezeki yang halal. Sebab, semua yang disediakan Allah itu harus diolah dan diusahakan lebih dahulu sebelum dimanfaatkan bagi keperluan hidup manusia. Dengan memahami ayat ini, dapat dikemukakan hal-hal yang berikut: 1. Allah memerintahkan agar manusia berusaha dan mengolah alam untuk kepentingan mereka guna memperoleh rezeki yang halal. Hal ini berarti bahwa tidak mau berusaha dan bersifat pemalas bertentangan dengan perintah Allah. 2. Karena berusaha dan mencari rezeki itu termasuk melaksanakan perintah Allah, maka

\footnotetext{
${ }^{30}$ Kementerian Agama RI, Al-Qur'an dan Tafsirnya, lihat https://risalahmuslim. id/quran/al-mulk/67-15. Diakses 27/8/2019.

31 Kementerian Agama RI, Al-Qur'an dan Tafsirnya, lihat https://risalahmuslim. id/quran/al-mulk/67-15. Diakses 27/8/2019.
} 
orang yang berusaha dan mencari rezeki adalah orang yang menaati Allah, dan hal itu termasuk ibadah. Dengan perkataan lain bahwa berusaha dan mencari rezeki itu bukan mengurangi ibadah, tetapi memperkuat dan memperbanyak ibadah itu sendiri. ${ }^{32}$

Diriwayatkan oleh Ahmad dari 'Umar bin al-Khaththab, sesungguhnya ia mendengar Rasulullah bersabda: Jika kalian benar-benar bertawakal kepada Allah, niscaya kalian akan diberi rezeki sebagaimana Allah memberikan rezeki-Nya kepada burung. Pergi mencari rezeki dengan perut yang kosong, dan petang hari ia kembali ke sarangnya dengan perut yang berisi penuh. (Riwayat at-Tirmidzi, Ahmad, al-Baihaqi, dan Abu Dawud dari 'Umar bin alKhaththab) Hadis ini menunjukkan bahwa waktu sejak pagi hari sampai petang adalah waktu untuk mencari rezeki, seperti yang telah dilakukan burung. Jika manusia benar-benar mau berusaha sejak pagi sampai petang pasti Allah memberinya rezeki. Mereka tidak akan kelaparan. Dari hadis ini juga dapat dipahami bahwa orang yang tidak mau berusaha tidak akan diberi rezeki oleh Allah. ${ }^{33}$

9. Menjalin Ukhuwah Makhluqiyah antara Manusia dan Alam.

Sesungguhnya semua mahluk ciptaan Allah yang ada di jagat raya ini adalah sama seperti manusia, yaitu sebagai hamba Allah atau dalam istilah Al-Qur'an disebut Umat (Umam), yang kesemuanya akan kembali kepada-Nya. Sebagaimana firman Allah:

Dan Tiadalah binatang-binatang yang ada di bumi dan burungburung yang terbang dengan kedua sayapnya, melainkan umat (juga) seperti kamu. Tiadalah Kami alpakan sesuatupun dalam Al-Kitab, kemudian kepada Tuhanlah mereka dihimpunkan. (alAn'âm/6: 38).

Di dalam Hasyiyah Showiy 'Ala Tafsir Jalâlain dan Tafsir Al-Mukhtashar. Markaz Tafsir di bawah pengawasan Syaikh Dr. Shalih bin Abdullah bin Humaid, Imam Masjidil Haram, maksud firman Allah di dalam QS, alAn'âm/6: 38 (Dan tiadalah binatang-binatang yang ada di bumi dan burung-burung yang terbang dengan kedua sayapnya, melainkan umat (juga) seperti kamu) adalah setiap jenis dari hewan-hewan tersebut memiliki aturannya sendiri-sendiri, seperti pekembangbiakan, cara hidup, interaksi, makanan, dan segala urusan kehidupannya Allah-lah yang menciptakannya sebagaimana Dia menciptakan kalian, memberinya rezeki sebagaimana memberi kalian rezeki, yang mana hal itu berada dalam ilmu dan takdir Allah yang meliputi segala sesuatu. Pendapat lain mengatakan yakni hewan-hewan tersebut seperti kalian dalam hal berzikir kepada Allah dan sebagai petunjuk akan kebesaran-Nya. (Tiadalah Kami alpakan sesuatupun dalam AlKitab) Yakni baik itu dari urusan-urusan kalian maupun urusan-urusan

\footnotetext{
${ }^{32}$ Kementerian Agama RI, Al-Qur'an dan Tafsirnya, lihat https://risalahmuslim. id/quran/al-mulk/67-15. Diakses 27/8/2019.

${ }^{33}$ Kementerian Agama RI, Al-Qur'an dan Tafsirnya, lihat https://risalahmuslim. id/quran/al-mulk/67-15. Diakses 27/8/2019.
} 
hewan-hewan tersebut. Yang dimaksud dengan al-kitab adalah lauhul mahfudz, Allah telah menetapkan didalamnya segala kejadian. ${ }^{34}$

\section{Membangun Kecerdasan Ekologis Berwawasan Gender}

Kecerdasan ekologis yang dimiliki manusia baik laki-laki maupun perempuan, didasari atas pengetahuan, kesadaran, dan keterampilan hidup yang selaras dengan kelestarian alam. Seseorang yang cerdas secara ekologis adalah orang yang memahami bahwa setiap prilaku dan tindakannya tidak hanya berdampak pada dirinya dan orang lain, melainkan juga pada lingkungan alam yang ditempati. ${ }^{35}$ Membangun kecerdasan ekologis berwawasan gender sangat penting dilakukan, agar alam tempat semua mahluk hidup berada, dapat terus terjaga kelestariannya.

Kecerdasan ekologis didukung oleh kecerdasan intelektual, kecerdasan emosional, sosial, dan bahkan kecerdasan spiritual. Kecerdasan intelektual merupakan kecerdasan yang paling mendapat tempat dalam dunia akademik. Kecerdasan emosi juga memiliki posisi yang sangat penting dalam berhadapan dengan orang lain dan alam sekitar, kecerdasan tersebut terdiri dari kemampuan melihat emosi orang lain, mengelola emosi, memotivasi diri, mengenal, dan mengembangkan hubungan dengan orang lain. ${ }^{36}$

Kecerdasan sosial, sebagai bagian yang mendukung kecerdasa ekologis, memiliki komposisi yang juga penting. Kecerdasan ini menggambarkan kemampuan memahami individu tentang pentingnya menjalin hubungan baik dengan orang lain dan lingkungan sekitar. Sedangkan kecerdasan spitual adalah kemampuan seseorang untuk menghadapi dan memecahkan masalah yang berhubungan dengan nilai, batin, dan kejiwaan. ${ }^{37}$ Kecerdasan ini terutama berkaitan dengan abstraksi pada suatu hal di luar kekuatan manusia yaitu kekuatan penggerak kehidupan dan semesta. ${ }^{38}$

Pada bagian bab ini penulis akan membahas tentang membangun kecerdasan ekologis berwawasan gender, diawali dari kecerdasan ekologis berwawasan gender, membangun kecerdasan ekologis melaui ekopedagogi dan aktualisasi kecerdasan ekologis berwawasan gender.

\section{Penutup}

Kesimpulan keseluruhan dari Penelitian ini adalah perspektif Al-Qur'an mengenai pendidikan lingkungan berwawasan gender yang mengusung teori ecopedagogis humanis teosentris, yakni teori yang memberikan gambaran tentang pendidikan ekologi bagi laki-laki dan perempuan yang bepusat pada membangun kesadearan teologis dalam upaya konservasi lingkungan. Melalui pendidikan lingkungan berwawasan gender ini diharapkan dapat membangun aksi nyata peserta didik dalam upaya menjaga kelestarian dan konservasi lingkungan.

${ }^{34}$ As-Syaikh Ahmad Showiy Al-Maliki, Hasyiyah Showiy 'Ala Tafsir Jalâlain, Jilid 2, Bairut Libanon: Darul Fikr, 1993, hal. 17. Referensi lain, lihat: https://tafsirweb.com/2162- suratal-anam-ayat-38.html. Diakses pada 27/9/2019.

${ }^{35}$ Supriatna, Ecopedagogy, Bandung: Rosdakarya, 2016, hal. 24.

${ }^{36}$ Supriatna, Ecopedagogy, ..., hal. 24.

37 http://www. sarjanaku. com/2013/01/ pengertian-kecerdasan-spiritual-ciri-sq html. Diakses pada 7-6-2019.

${ }^{38}$ Danah Zohar dan Ian Marshal, Memanfaatkan Kecerdasan Spritual dalam Berfikir Integralistik dan Holistik untuk Memaknai Kehidupan, Bandung: Mizan, 2000, hal. 4. 


\section{Daftar Pustaka}

Al-Qur'an al- Karim.

Abas, M. et-al, Pendidikan Lingkungan Hidup, Jakarta: Erlangga, 2015.

Abdullah, Burhanudin, Menanti Kemakmuran Negeri: Kumpulan Esai tentang pembangunan Sosial Ekonomi Indonesia, Jakarta: Gramedia, 2006.

Abdurrahman, et-al (edit) Agama Dan Masyarakat, Yogyakarta : IAIN Sunan Kalijaga, 1995.

Abercrombie, Nicholas, Stephen Hill, Bryan S.Turner, Kamus Sosiologi, Yogyakarta: Pustaka Pelajar, 2010.

al-Abrasyi, Muhammad Athiyah, Dasar-dasar Pendidikan Islam, Jakarta: Bulan Bintang, 1980

------, Beberapa Pemikiran Pendidikan Islam, terj. Syamsudin Asyrofi dkk. Yogyakarta: Titian Ilahi Press, 1996.

-------, Dasar-Dasar Pokok Pendidikan Islam, Yogyakarta: Titian Ilahi Press, 1996.

Adz-Dzakiey, Hamdani Bakran, Prophetic Intelligence, Yogyakarta: Islamika, 2004.

Afifi, Faisal. Integritas dan Kepemimpinan Inovatif, dalam http//: www.buku-bisnis.com/wp.../Integritas-dan-Kepemimpinan-Inovatif.pdf.

Diakses pada 15 Januari Ahid, Nur, Pendidikan Keluarga Dalam Perspektif Islam, Yogyakarta: Pustaka Pelajar, 2010.

Ahmadi, Abu Bakar, Psikologi perkembangan, Bandung: Rineka Cipta, 1991, 2016.

al-Arafi, Ahmad Bin Abil A'la, Syarah Tanqih al-Fusul fi ikhtisar al Manssul, Mesir: Dar al-Fikr, 1973.

al-Ghazali, Imam Abi Hamid Muhammad Ibn Muhammad, Ihya' 'Ulum al-Din, Cairo: Maktabah al-Imam li al-Nushur wa al-Tauzi', 1417 H/1996 $\mathrm{M})$, cet. I.

-------, Khulq al-Muslim, Damsyiq: Dâr al-Qalam, 1416 H/1996 M.

-------, Musykilât fî̀ Tharîq al-ㅂayât al-Islâmiyyah, al-Qâhirah: Dâr al-Basyîr, tth. University Press, 1985.

Ali, Atabik dan Muhdlor A. Zuhdi, Kamus Al-'Ashriy, Yogyakarta: Multi Karya Grapika, 2004.

Ali, A. Mukti, Agama dan Pembangunan di Indonesia, Jilid I. Jakarta: Biro Hukum dan Humas DEPAG, 1971/1978.

------,, Alam pikiran Islam Modern di Indonesia, Yogyakarta: Yayasan Nida, 1971.

------,, Beberapa Masalah Pendidikan di Indonesia, Yogyakarta: Yayasan Nida, 1971.

Beberapa Persoalan Agama Dewasa ini, Jakarta: Rajawali Press, 1981.

------, Etika Agama dalam membentuk Kepribadian Nasional dan Pemberantasan Kemaksiatan dari Segi Agama Islam, Yogyakarta: Yayasan Nida, 1969.

------, Faktor-faktor Penyiaran Islam, Yohyakarta: Yayasan Nida, 1971. 
------, Memahami Beberapa Aspek Ajaran Islam, Bandung: Mizan, 1990.

------, Metode Memahami Agama Islam, Jakarta: Bulan Bintang, 1991.

------, "Universitas Islam Indonesia: Harapan dan Pengembangannya" Dalam Setengah Abad UII, Yogyakarta: UII Press, 1994

------, Mengenal Pondok Tremas dan Perkembangannya, Tremas, 1986.

, "KH. Ali Ma'shum Itu Guru Saya” dalam KH. Ali Ma'shum Perjuangan Dan Pemikirannya, Yogyakarta: Multi Karya Grafika, 1989.

Aly, Hery Noer. Ilmu Pendidikan Islam, Jakarta: Logos, 1999 cet I.

Amir, Sulfikar. Diskriminasi Sains terhadap Perempuan, Rensselaer Polytechnic Institute, lihat http://www. kimianet. lipi. go.id/ utama. cgi? Artikel \&1105154151\&1.

Amirudin, Mariana. "Pendidikan: Syarat Mutlak Manusia Berkualitas" Jurnal Perempuan, No. 66. 